Niniejsza publikacja jest dostęna na licencji Creative Commons. Uznanie autorstwa-Użycie niekomercyjne-Bez utworów zależnych 3.0 Polska. Pewne prawa zastrzeżone na rzecz autora. Zezwala się na wykorzystanie publikacji zgodnie z licencja - pod warunkiem zachowania niniejszej informacji licencyjnej oraz wskazania autora jako właściciela praw do tekstu. Treść licencji jest dostępna na stronie: http://creativecommons.org/licenses/by-nc-nd/3.0/pl/

\title{
Istvan KECSKES, Intercultural Pragmatics. Oxford University Press, Oxford/New York, 2014, 277 str.
}

Istvan Kecskes jest powszechnie uważany za jednego z pionierów pragmatyki interkulturowej, co zawdzięcza nie tylko licznym publikacjom z tego zakresu, ale też podejmowanym na szeroką skalę działaniom na rzecz propagowania tej dyscypliny. Jest między innymi założycielem i redaktorem naczelnym czasopisma Intercultural Pragmatics, funkcjonującego od 2004 roku, a także jednym z głównych organizatorów „Międzynarodowej Konferencji nt. Pragmatyki Interkulturowej i Komunikacji (INPRA)". Jego monografia Intercultural Pragmatics to publikacja, która omawia podstawy teoretyczne i metodologiczne tej stosunkowo młodej, ale dynamicznie rozwijającej się subdyscypliny pragmatyki.

W ostatnich dziesięcioleciach, wraz ze wzrostem znaczenia komunikacji międzykulturowej w zglobalizowanym świecie, wyraźnie wzrosło także zainteresowanie perspektywą interkulturową w badaniach językoznawczych. Również teorie pragmatyczne, przez długi czas koncentrujące się głównie na interakcjach pomiędzy mówcami monolingwalnymi z tego samego kręgu kulturowego, zostały włączone w ten nurt badawczy.

Współcześni pragmatycy kładą nacisk nie tylko na takie aspekty komunikacji jak intencjonalność, kooperacja czy relewancja, ale przede wszystkim podkreślają rolę wiedzy wspólnej w działaniach językowych. Jeśli chodzi o pojęcie wiedzy wspólnej, szczególną popularność zyskały tu dwa podejścia. Zgodnie z pierwszym (zob. R.C. Stalnaker 1978; H.H. Clark/ S.E. Brennan 1991) wiedza wspólna (ang. common ground) jest postrzegana jako konstrukt mentalny istniejący a priori, aktywowany dopiero w interakcjach komunikcyjnych, $\mathrm{tj}$. w sytuacjach, w których mamy do czynienia ze swoistym transferem wiedzy pomiędzy interaktantami. Drugi, bardziej dynamiczny model wiedzy wspólnej (zob. H.C. Arnseth/ I. Solheim 2002; R.B. Arundale 2008; T. Koschmann/ C.D. LeBaron 2003) zakłada, że wiedza wspólna nie jest gotowym konstruktem, lecz jest współkonstruowana przez każdego z interaktantów na bieżąco w czasie komunikacji - metodą prób i błędów. I. Kecskes w recenzowanej publikacji proponuje ujęcie socjo-kognitywne wiedzy wspólnej, które łączyłoby główne założenia obydwu podejść.

Rozdziały 1. i 2. monografii I. Kecskesa opisują ramy teoretyczne pragmatyki interkulturowej oraz jej powiązania z innymi gałęziami pragmatyki. Rozdział 3. z kolei koncentruje się na pojęciu kompetencji pragmatycznej oraz jej potencjalnym wpływie na drugi język (L2 $\left.{ }^{1}\right)$. W pragmatyce interkulturowej kompetencja pragma-

\footnotetext{
${ }^{1}$ Skróty L1 i L2 odnoszą się odpowiednio do języka pierwszego (rodzimego, ojczystego) i języka drugiego (obcego) dla mówcy.
} 
tyczna, czyli umiejętność rozumienia języka w kontekście oraz jego efektywnego użycia do realizacji celów komunikacyjnych (J. Thomas 1983: 92), jest postrzegana jako struktura niestabilna i dynamiczna, zależna od czynników takich jak: wiek, motywacja, ilość i jakość kontaktu z językiem docelowym czy uwarunkowania socjokulturowe. W odniesieniu do kształtowania się kompetencji pragmatycznej I. Kecskes wskazuje na różnicę pomiędzy socjalizacją konceptualną a językową, kładąc nacisk na specyfikę tych procesów w przypadku L2. Niemożliwe jest nabycie umiejętności komunikacji interpersonalnej w języku L2 w sposób identyczny czy podobny do L1; socjalizacja konceptualna w L2 bazuje w znacznym stopniu na socjalizacji nabytej w L1.

Rozdział 4. jest poświęcony pojęciom wiedzy ogólnej (encyklopedycznej), modelom kulturowym oraz tzw. ,interkulturom”. Te ostatnie według I. Kecskesa to swego rodzaju reprezentacje mentalne, które są konstruowane wspólnie podczas interakcji i opierają się zarówno na normach społeczno-kulturowych, jak i pojawiających się przesłankach o charakterze czysto kontekstualnym (sytuacyjnym). W rezultacie mamy do czynienia $\mathrm{z}$ dyskursem interkulturowym, w którym nie następuje przepływ wiedzy, ale jej ciągła transformacja. Ponadto autor pokazuje, jak modele kulturowe wpływają na kształtowanie się interkultur.

W kolejnym, 5. rozdziale I. Kecskes podkreśla rolę języka formulaicznego w budowaniu kompetencji pragmatycznej. Pod tym pojęciem kryją się różnego typu „prefabrykaty językowe”, a więc kolokacje, związki frazeologiczne, metafory, idiomy, czyli wszelkie wyrażenia, które są przechowywane i aktywowane całościowo. Dlaczego język formulaiczny jest tak istotny dla pragmatyki interkulturowej? Według I. Kecskesa odzwierciedla on zachowania mówców rodzimych, wyraża wartości kulturowe oraz normy społeczne. Formuły językowe są skonwencjonalizowane, ich użycie spełnia określone funkcje społeczne, a więc ich właściwa selekcja w odpowiednim kontekście wskazuje na poziom biegłości językowej, a zwłaszcza biegłości pragmatycznej.

W rozdziałach 6., 7. i 8. I. Kecskes omawia odpowiednio trzy kluczowe pojęcia w pragmatyce interkulturowej: kontekst, wiedzę wspólną oraz wyrazistość (ang. saliency). Autor podkreśla specyfikę wiedzy wspólnej w interakcjach mówców o różnym pochodzeniu kulturowym (chodzi tu innymi słowy o wysoki stopnień niepewności co do konwencji społecznych i kulturowych, doświadczeń czy poglądów drugiego uczestnika komunikacji). Co więcej, I. Kecskes twierdzi, że znaczenie słów może tak samo zależeć od kontekstu, jak i wyrazistości komunikatu. Najbardziej wyraziste (tj. konwencjonalne czy też prototypowe) znaczenia (ang. salient meanings) są aktywowane automatycznie i początkowo nie wiążą się z procesami kontekstualizacji. W niektórych nawet przypadkach stopień wyrazistości może być na tyle silny, że kontekst sytuacyjny nie jest w stanie skorygować niewłaściwej interpretacji danego wyrażenia czy jednostki leksykalnej. Może mieć to miejsce np. w przypadku idiomów, kiedy to użytkownicy języka docelowego w pierwszej kolejności opierać się będą na ich znaczeniu dosłownym. 
W rozdziale 9. autor przygląda się bliżej zagadnieniu grzeczności w komunikacji interkulturowej, podkreślając jej specyfikę i wskazując na zasadnicze różnice pomiędzy głównymi założeniami dotychczasowych modeli teoretycznych a podejściem socjo-kognitywnym. Dotyczą one przede wszystkim trzech aspektów komunikacji interkulturowej, opartej na użyciu lingua franca: intencjonalności, kontekstu oraz wiedzy wspólnej, zwłaszcza w odniesieniu do norm i oczekiwań kulturowych. Trudno nie zgodzić się z tezą I. Kecskesa, według której uczestnicy dyskursu interkulturowego tylko w ograniczonym stopniu współdzielą przekonania, konwencje czy modele kulturowe, co naturalnie niesie ze sobą istotne implikacje dla postrzegania określonych zachowań jako grzeczne lub nie. Niestety w komunikacji międzykulturowej kontekst sytuacyjny nie zawsze będzie pomocny we właściwej ocenie wypowiedzi, ponieważ może być on różnie interpretowany ze względu na odmienną historię doświadczeń społeczno-kulturowych uczestników komunikacji.

W ostatnim rozdziale I. Kecskes przedstawia metody, które uważa za najbardziej efektywne w badaniach nad pragmatycznymi aspektami komunikacji interkulturowej: analizę konwersacji, analizę korpusową i analizę dyskursu. Wybór powyższych metod wynika z założenia, że pragmatyka interkulturowa powinna koncentrować się na użyciu języka zarówno w interakcjach realizowanych za pomocą mowy, jak też za pomocą pisma, w tym także z wykorzystaniem komputerów.

Dużą wartością książki jest podjęcie rozważań nad kulturowymi podstawami interakcji językowej z perspektywy bilingwalnej i multilingwalnej. Takie podejście umożliwia nowe i bardziej kompleksowe spojrzenie na procesy tworzenia znaczenia w ogóle, a tym samym stawia kwestię uniwersaliów pragmatycznych w nowym świetle. I. Kecskes podkreśla, że pragmatyka teoretyczna koncentruje się przede wszystkim na komunikacji monolingwalnej, co zasadniczo nie odzwierciedla w pełni procesów tworzenia i interpretacji znaczenia, i jednocześnie słusznie zwraca uwagę na specyfikę komunikacji interkulturowej. W tym drugim przypadku mamy bowiem do czynienia z mówcami, których charakteryzuje swego rodzaju synergia kognitywna, wynikająca z połączenia różnych systemów językowych, konceptualnych oraz socjokulturowych; V. Cook $(1996,1997)$ określa ten fenomen jako „multikompetencję”, natomiast I. Kecskes (2010) jako „system dualny” lub „system multilingwalny". Trudno nie zgodzić się z autorem, że nieuzasadnione wydaje się być stawianie znaku równości pomiędzy interakcją typu L1 - L2 a L1 - L1, ponieważ mówca bilingwalny, używając jednego ze swoich języków, nie staje się tymczasowo jego mówcą rodzimym, lecz cały czas łączy w sobie zróżnicowane systemy kognitywno-językowe.

Chociaż I. Kecskes w centrum zainteresowań pragmatyki interkulturowej wyraźnie stawia dyskurs typu L1 - L2, a więc interakcje, w których jednym z uczestników jest mówca rodzimy, można odnieść wrażenie, że w znacznie większym stopniu koncentruje się na dyskursie typu L2 - L2. Z pewnością model analizy zaproponowany przez I. Kecskesa obejmuje różne warianty w dyskursie bi- i multilingwalnym, nie mniej jednak bliższe spojrzenie na interakcje typu L1 - L2 mogłoby być dodatkowym atutem książki. Być może umożliwiłoby ono głębsze zrozumienie różnic (i ich znaczenia w interakcji) pomiędzy komunikacją L1 - L2 a L2 - L2, odnoszących 
się np. do stopnia znajomości języka docelowego (język rodzimy versus język obcy) czy związanych z nim konwencji kulturowo-społecznych, wynikających z procesu socjalizacji.

Głównym celem publikacji Intercultural Pragmatics było przedstawienie modelu socjo-kognitywnego pragmatyki interkulturowej. Do najistotniejszych osiągnięć jej autora należy zaliczyć m.in. porównanie pragmatyki interkulturowej z pragmatyką interjęzyka ${ }^{2}$ oraz pragmatyką intrakulturową. Już samo opracowanie modelu komunikacji interkulturowej, dotychczas $\mathrm{w}$ dużej mierze zmonopolizowanej przez pragmatykę interjęzyka, koncentrującą się zwykle na paradygmacie dydaktycznym (rozwój kompetencji pragmatycznej w procesie nauczania języka obcego), było przedsięwzięciem bardzo ambitnym. Należy je również uznać za przedsięwzięcie udane.

Jak słusznie sugeruje I. Kecskes, do stworzenia kompleksowego modelu teoretycznego, opisującego użycie języka w kontekście społecznym, niezbędne jest nowe podejście do komunikacji interkulturowej, a mianowicie włączenie jej w główny nurt badań pragmatycznych. Intercultural Pragmatics to pozycja, która bez wątpienia oferuje świeże spojrzenie na klasyczne teorie komunikacji i może stać się inspiracją do poszerzenia badań o perspektywę interakcji interkulturowych, zwłaszcza w odniesieniu do procesów kształtowania i konstruowania wiedzy wspólnej w komunikacji interkulturowej, jak również takich zagadnień jak grzeczność, język formulaiczny czy intencjonalność.

\section{Bibliografia}

Arnseth, H.C./ I. Solheim (2002), Making sense of shared knowledge, (w:) G. Stahl (red.), Proceedings of CSCL 2002 on Computer Support for Collaborative Learning: Foundations for a CSCL community. Hillsdale, NJ, 102-110.

Arundale, R.B. (2008), Against (Gricean) intentions at the heart of human interaction, (w:) ,Intercultural Pragmatics” 5(2), 229-258.

Clark, H.H./ S.E. Brennan (1991), Grounding in communication, (w:) L.B. Resnick/ J.M. Levine S./ D. Teasley (red.), Perspectives on Socially Shared Cognition. Washington, DC, 127-149.

Cook, V. (1996), Competence and multi-competence, (w:) G. Brown/ K. Malmkjaer/ J. Williams (red.), Performance and competence in second language acquisition. Cambridge, 57-69.

Cook, V. (1997), Monolingual bias in second language acquisition research, (w:) Revista Canaria de Estudios Ingleses 34, 35-50.

\footnotetext{
${ }^{2}$ Termin interjęzyk (ang. interlanguage) pochodzi od L. Selinkera (1972) i odnosi się do systemu językowego używanego w procesie uczenia się języka obcego. Specyfika tego systemu jest związana m.in. z procesem konstruowania nowych reguł językowych, inferencją L1 oraz interakcją pomiędzy L1 a L2. Teoria interjęzyka odegrała istotną rolę w badaniach nad akwizycją drugiego języka oraz rozwojem badań na pragmatyką interjęzyka (zob. np. G. Kasper 1989; L. Selinker 1992; G. Kasper/ S. BlumKulka 1993).
} 
Kasper, G. (1989), Variation in interlanguage speech act realization, (w:) S. Gass/ C. Madden/ D. Preston/ L. Selinker (red.), Variation in second language acquisition: Discourse and pragmatics. Clevedon/ Philadelphia, 7-58.

Kasper, G./ S. Blum-Kulka (red.), (1993). Interlanguage pragmatics. New York.

Kecskes, I. (2010), Dual and multilanguage systems, (w:) Journal of Multilingualism 7(2), 1-19.

Koschmann, T./ C.D. LeBaron (2003), Reconsidering common ground: Examining Clark's Contribution Theory in the OR, (w:) K. Kuutti/ E.H. Karsten/ G. Fitzpatrick/ P. Dourish/ K. Schmidt (red.), Proceedings of the Eighth European Conference on Computer-Supported Cooperative Work. Dordrecht/ Boston/ London, 81-98.

Selinker, L. (1972), Interlanguage, (w:) „IRAL” 10, 209-30.

Selinker, L. (1992), Rediscovering interlanguage. London.

Stalnaker, R.C. (1978), Assertion, (w:) P. Cole (red.), Syntax and Semantics 9: Pragmatics. New York, 315-332.

Thomas, J. (1983), Cross-cultural pragmatic failure, (w:) Applied Linguistics 4(2), 91-112.

Kamil ZUBRZYCKI

Uniwersytet Warszawski 